\section{THE SANITARY RECORD OF THE MANEUVER DIVISION *}

I. R. KEAN, M.D.

Ilentenant-Colonel, Medical Corps, U. S. Army

WASHINGTON. D. C.

Since July 10 the most of the organizations composAnt the Maneuver Division of regular troops at San lt is, the 'Texas, have been returned to theil' stations.' conditions an anpropriate time to review the health which lons and sanitary alministration of this camp, Army las established a record that is unique in our its sanitar the smallness of its sick-list, the excellence of ization of arrangenents and the completeness in organsisted of its medical department. 'The division contwo of artight regiments of infantry, two of cavalry, corps, artillery, and the usual quotas of engineers, signal the regind hospital corps. The latter had in addition to hospitalsent, four ambulance companies and four field as the These were complete in equipment so far ambulanedical Department could supply them, but one supplied by company and one field hospital were never mounts by the Quartermaster's Department with their thount and draft animals. As regards personnel, alto an every garrison in the United States was stripped hospital ucible minimum to supply medical officers and deficiency corps men for these organizations, there was a below the of twenty-one medical officers and 129 men impair the authorized strength. This did not seriously for field efficiency of the medical service of the division strength work, as it was itself much below its tactical 20,000 , having only about. 12,000 men instead of nearly facts derich it should lave at war strength. These quacy of the rated clearly, however, the numerical inadea second the medical establishment of our Army, and if seemed division had been called out, as at one time been acoloble, the situation in this respect would have plies foute. The complete medical equipment and sulpbeds for the division, including a base hospital of 500 shipped two evacuation hospitals of 324 beds each were and St from the Ficld Medical Depots at Washington pital Louis, accompanied by a detuchment of the Hosat San to prevent loss or side-tracking, and arrived San Antonio before the last troops were detrained.

\section{SANITARY ARRANGEMENTS}

A portable field laboratory was for the first time added and medical equipment of this division for diagnostic lished sunitary purposes. The base hospital was estabthe at the neighboring post, Fort Sam Houston, for pitals whion of serious cases, but the evacuation lonsnientich were intended for use on the line of commuThe rions, not being needed, were not manned or opened. Bimingef surgeon of the Division was Col. H. P. Straublim, and the sanitary inspector Major Paul 15 . latter, both of the Medical Corps, U. S. Army, and the Thember of the General Staff.

importansposal of wastes is a matter of elementary opments in camplife and new and interesting develtion of were reached in this camp. In the vexed quesbeen therposal of excreta, the old latrine pit, which had the shoroughly discredited by the better experience of milk of sim $_{1}$ war was succeded by the trough filled with and of lime and emptied by an odorless excavator wagon which pump which was devised by the distinguished board wich investigated the camp epidemies of typhoid fever

1. Tublished by nuthorlty of the Surgeon-Feneral.

the the muneuver divlston went out of existence on August 7 and H.jgader-Gemalning complise a brigade under the command of sader-General Haiph W. Hoyt in 1898 and of which Reed, Vaughan and Shakespeare were the members. This system broke down in rainy or freezing weather and in sandy soils and was gradually displaced by the theoretically perfect, but practically cumbrous incinerators, which did good service in fixed camps and with skilled handling, but were not mobile and were very costly. The mobilization of March 6 was so unexpected and so rapid that no time was given for the purcliase and erection of these elaborate constructions and so a system was adopted which has been pre viously tried on a small scale. $\Lambda$ narrow, deep trench, 18 to 24 inches wille, is dug and over it is placed a box seat, entirely fly-proof, with self-closing covers and a urimal at one end. This sink-box, as Harvard terms it in his excellent "Military Hygiene," can be knocked down for transportation, is movable, and is removed once a day, and the pit burned out with hay sprinkled with crude petroleum. The box was at the same time cleaned and then replaced. The contents of the pit were in this way sterilized so as to give no putrefactive odor after even three months of use. Besides the greater simplicity, mobility and quickness of installation of the sink-box as compared with incinerators, the Quartermaster's Department estimated that the cost of the sink-box system was $\$ 900$ a month for the whole camp, whereas incinerators of an approved type would cost for material and labor $\$ 30,000$ a month. The kitchen wastes, both solid and liquid, were also consumed by fire, in a kitchen creniatory which consisted of a shallow pit a foot deep, $41 / 2$ feet long, and $21 / 2$ feet wide, filled to the level of the enrth with broken stone and surrounded by a wall of clay or stones a foot high. A fire was kept burning on this and consumed all garbage thrown on it while the heated stones quickly evaporated the slops.

Horses in camp were tied side by side to a heavy rope called a picket-line and so their ilroppings were easily collected and with the straw bedding hauled away and burned. The picket-line areas were also sterilized once a week by burning them over with straw and crucle petroleum, thus effectually disposing of the fly larva and of all odors. 'Ten gallons of oil were used for each burning of a picket line. These several precautions effectunlly kept down the number of flies and afforded no opportunity for their access to infectious material.

The sanitary police of the camp in other respects also was rigidly supervised by the melical officers, so that this crowded camp site, which had been used continuonsly for four months, when vacated presented nothing offensive to sight or smell.

The water-supply was from the water system of Fort Sam Houston and was artesian in origin and entirely above suspicion.

\section{IIEALTH OF 'THE TROOPS}

The health of military commands is usually measured by the constantly non-effective rate which represents the average number constantly sick in each thousand men. 'This was for the Maneuver Division 22 per thousand up to the first of July, and its smallness can be appreciated when it is stated that this rate was 34 for all troops in the United States for the year 1910. In other worls, the health of these soldiers in camp, sometimes living in deep mud and at other times in clouds of dust and under a semitropical sun, was better than in barracks surrounded by the comforts and sanitary appliances of post life.

The largest cause of morbidity was venereal diseases (4 per thousand), and next came measles and mumps ( 3 per thousand), the latter affecting almost exclusively the 
newly arrived recruits. The actual number of admissions for the more important camp diseases were: typhoid fever, two; malaria, nine, all benign tertians; simple diarrhea, 119 ; dysentery, twenty-nine.

\section{TYPHOID PROPIIYLAXIS}

Perhaps one-fourth of the troops arrived at San Antonio already immunized by voluntary antityphoid inoculations given them at their posts. It was concurrently determined by the Division Commander and the War Department that the time had arrived to make this procedure compulsory for troops taking the field, and it was so ordered and carried out as rapidly as the prophylactic culture could be supplied from the laboratory of the Army Medical School. The technic was simple. The site of puncture, usually the outer side of the left arm, was sponged off with alcohol and a small area sterilized with tincture of iodin, the injection made with a sterile syringe and the puncture sealed with collodion. The first dose is 0.5 c.c., the second and third being 1 c.c. each. An interval of ten days is allowed between doses, the entire procedure thus taking twenty

\section{8}

TABLE SHOWING FOR THE REGIMENTS OF THE SICOND DIVISION OF THE SEVENTH ARMY COLPS, ASSEMIBIED A'T JACLSONVILLE, FIA., THE MORTALI'T AND MORBIDI'Y FLOM TYPIIOID FEVER

\begin{tabular}{|c|c|c|c|c|c|}
\hline & & Typl & $\begin{array}{l}\text { ises of } \\
\text { old frver }\end{array}$ & $\begin{array}{l}\text { Denths } \\
\text { from }\end{array}$ & $\begin{array}{l}\text { Dentlis } \\
\text { from }\end{array}$ \\
\hline & Mnnn & Col- & Certain & Typhold & All \\
\hline $\begin{array}{l}\text { Regiments } \\
\text { Second lllinols }\end{array}$ & Strougth & tain & nod l'robable & Fever & Ibsellises \\
\hline $\begin{array}{l}\text { Second Illinols } \\
\text { Clinst }\end{array}$ & 1,0415 & 253 & $3+1$ & 18 & $2 \underline{2}$ \\
\hline Finst North Culolln & a 1,$11 ; 4$ & $1+7$ & דבעביבים & 16 & 20 \\
\hline Second New Jelsey. & . $1,1 \mathrm{in}$ & jरs & 318 & 29 & 32 \\
\hline Filst Wisconsin ... & . 1.2732 & $\because 109$ & $\$ 11$ & 413 & 48 \\
\hline Iiftleth lown ..... & . 1,0197 & 164 & 207 & $3: 1$ & 33 \\
\hline Ninth Illinois $\ldots \ldots$ & . 1,288 & 153 & 248 & 18 & 28 \\
\hline Second Vlirginia ... & . 1.:2010 & 105 & 152 & 17 & 20 \\
\hline Fourth virginla .... & - 1,274 & j35 & $2: 31$ & 21 & 28 \\
\hline Forty-Ninth Iowa.. & - $1,2: 16$ & 378 & (612 & 50) & 50 \\
\hline 10 & $.10,750$ & $1.7 \pm 0$ & $\because 603$ & 248 & 281 \\
\hline
\end{tabular}

1911

T.ABLE SHOWING FOI 'TIE ORGANIZATIONS COMHOSINO

THE MANLUVER DIVISION AT SAN AN'TONIO, TLXIS, PHL MOIBIDITY ANI MOR'TALITY FROM TYPIOHD FEVIR, MARTII 10 TO . IULY 10, 1911*

\begin{tabular}{|c|c|c|c|c|}
\hline Orgnization & $\begin{array}{l}\text { Meun } \\
\text { Sflength } \\
\text { Jume }\end{array}$ & $\begin{array}{c}\text { Cnses of } \\
\text { Typlinld } \\
\text { Cer. ind Prob. }\end{array}$ & $\begin{array}{l}\text { Dentis fiom } \\
\text { ryplioid } \\
\text { fiever }\end{array}$ & $\begin{array}{l}\text { I)enthy } \\
\text { froun } A \text { ll } \\
\text { llsenses }\end{array}$ \\
\hline Eleventh infantry & $12+4$ & . & $\cdots$ & \\
\hline Fifteenth infuntry $\ldots$. & (4)(it) & & . & 2 \\
\hline Clubteenth infantry .... & $1,(1 \geq \div 2$ & $\cdots$ & . & . \\
\hline Thileenth infuntry .... & 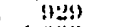 & . & . & . \\
\hline Twenty-second Infintry. & 1.033 & $\ldots$ & $\ldots$ & \\
\hline Tenth Infantry $\ldots \ldots \ldots$ & $1.011 \mathrm{i}$ & . & .. & i \\
\hline Seventeontl infantry ... & 954 & $\therefore$ & . & . \\
\hline Twenty-elghth infunitry. & 1.51 & . & . & \\
\hline Third told artllery. . . . & $8+7$ & .. & . & 2 \\
\hline Fourth fleld artlllery.... & $i+1$ & .. & . & $\overline{1}$ \\
\hline Wngineer battullon ..... & 5316 & .. & .. & $i$ \\
\hline Stgnal corps $\ldots \ldots \ldots \ldots$ & 1117 & - & $\cdots$ & - \\
\hline Ninth cavalry & 7tt & $\therefore$ & .. & \\
\hline Eleventh cuvidly ...... & $1.1+: 3$ & . & $\cdots$ & 3 \\
\hline Sanftary troops ....... & $7 ! n$ & $1 \dagger$ & . & 1 \\
\hline Total. . &.$\$ 101$ & 1 & 0 & 11 \\
\hline
\end{tabular}

* In addition to the alove a civilian temanstel. not immuml\%od, was admitted for typhoid ferer in April.

$t$ 'Juls putient, a priyate of the hospital corps, land not completed his Immunization, linvlug tuken only two doses. 'l'he cuse was very mfld and would perlaps have been overlooked but for the tule that blood cultures were nade in all cuses of fever of over porty-alght hours duration. The Wldal reaction has no diagnostle vilue in immunized persons, is all respond to it. Forty-nine cuses of typlioid fever wlth nineteen deraths were reported as occurring in the city of Bus antonlo during this period.

days. The injection is made into the subeutancous connective tissue and not into the muscles. 'There was practically no puncture infection, and the reaction was mild or absent in 90 per cent. of the cases trented. In no case was it followed by serious results. There were uj) to July 1, 8,097 men immunized.

The immense advance in camp sauitation and particularly the value of this protective measure can be estimated by comparing the typhoid incidence of this camp with that of the Second Division, Seventh Almy Corps, which was organized at Jacksonville, Fla., about June 1, 1898, and remained there in camp until October; some of the regiments leaving in September. This division was not conspicuously unfortunate in its typhoid record for that time, and is selected because of the close similarity of its conditions of service to those of the Maneuver Division. The two divisions were encamped in nearly the same latitude and for about the same length of time, and cach had a good camp site and an artesian water-supply of unimpeachable purity. While the period in camp of the Second Division, Seventl Army Corps was later in the yenr, the number of men involved is larger for the Maneuver Division. The accompanying table referring to the former is taken from the celelorated "Report on 'Typhoid Fever in U. S. Military Camps in the Spanish War," by Reed, Vauglan and Shakespeure, Vol. 1, page 609 .

\section{REPOR'T ON 140 RECENT CASES OF PSORI- ASIS IN PRIVATE PRACTICE UNDER A S'TRICTLY VEGETARIAN DIE'I* *}

L. DUNCAN JUULKLEY, A.M., M.D.

Physiclan to the New York Skin and Cane'l IIospltal, Consilting I'hysiclut to the New York Lospltal, etc. NEW YORK

In spite of repeated communications ${ }^{1}$ on the subject the medical profession still does not seem to realize the value of a strictly vegetarian diet in psoriasis; and yet I could refer to many intelligent patients in private practice who have said, "You may quote me as a striling instance of the unquestionable value of this element in treatment."

It occurred to me, therefore, to keep a list of pationts in private practice whom I had observed and treated during the past two years, and who have been under a vegetarian diet, and, after studying their records, to present the results obtained; the total number of the cases is 140. Some of the patients have been under olservation and more or less treatment for many vears; the larger proportion of them were first seen during the past two years; but, as will be mentioned later, the older and the newer cases alike confirmed the value of $a$ strictly vegetarian diet, often in a very striking manner. It should be stated that earcful notes were recorded of all these cuses, and full entries made at each and every visit; I may add that most of the cases to be analyzed were also watched by my office associate, Dr. Paul E. Bechet, who is equally impressed with myself in regard to the beneficial effect of the plan advocated.

Psoriasis is such an inveterate disease that many patients applying for treatment are often convinced by what they have heard from physicians and others that the disease is incurable, and it is often very difficult to get the patient to submit to the proper dietary treatment for a long enough period to secure perfect results. Moreover, it not infrequently happens that even while maintaining a strictly vegetarian diet, there will be an outbreak of the eruption, more or less severe, and the patient is naturally discouraged, and may drop the diet. not recognizing that there are other causes which may

* IRend in the Section on Pharmacology and Therapeutics of the Amerienn Medical Assoclation, tht the Sixty-Second Annual Session

held at Ios Angeles, I une, 1011. I'r. Med. Soc. New York, 1805 , p. 151 ; 'Tr. Third Internat. Congres: of Dermatol, Iondon, 1800,1 . 734 ; Tiz Journal A. M. A., Nov. 17. 1000, p. 1030 . 